\title{
Municipal Solid Waste Management Challenges and Problems for Cities in Low-Income and Developing Countries
}

\author{
Mahmood Zohoori \\ Master of Environmental Management \\ Putra University of Malaysia \\ Birjand, Iran
}

\author{
Ali Ghani \\ Master of Business Administration (MBA) \\ Industrial Management Institute \\ Birjand, Iran
}

\begin{abstract}
Solid waste management is a challenge, problem as well as opportunities for the cities' authorities in developing countries especially low-income ones mostly because of the enhancing generation of waste, the burden posed on the budget of municipalities as a consequence of the high expenses belonged to its management, absence of the perception over a variety of factors which affect the various stages of management of waste and linkage essential to provide the whole handling system functioning. The data and information provided is very beneficial for changing, implementing or planning waste management system in towns. This article brings a general overview of state of municipal solid waste management (MSWM) by domestic authorities and available condition and current challenges of solid waste management (SWM) in developing countries particularly low-income ones. In addition, approaches of feasible solution which can be undertaken to prosper municipal solid waste (MSW) services are discussed. Approximately poor economic growth of the low-income developing countries annually has resulted in a rise in the poverty levels. Besides, migration from rural zones to urban zones has resulted in an unplanned settlements in suburban areas accommodation. Furthermore political interference prevents the smooth running of the domestic authorities. Vulnerability of surface and groundwater pollution is increasing due to lack of surveillance of local authorities in considering the environmental impact in siting MSW disposal sites. Illicit dumping of MSW on the roadside or river banks demonstrates economic and environmental threats on suburb properties. There are also lack of servicing of MSW collection vehicles, poor state of infrastructure and inadequate funding and budget which fight against the optimization of MSW disposal service. The rural economy requires to be developed if the migration of rural-urban areas is to be handled. In addition, involvement of stakeholders is necessary to obtain any meaningful and sustainable municipal solid waste management. Successful usage of low-tech approaches, and the association of informal refuse scavengers and collectors exist in different Asian, African and Latin American towns. Besides, a decentralized system can help solve the apparently intractable challenges and problems of waste management in low-income developing country cities in a socially favorable, economically viable, and environmentally sound manner.
\end{abstract}

Keywords: Solid Waste Management, Stakeholders, Low income, NGOs, Asian, African, Latin American, Migration, Economy

\section{INTRODUCTION}

Population growth, rapid urbanization, booming economy, and the increase in standards of living in a community have substantially enhanced the rate of municipal solid waste generation in developing countries (Minghua et al., 2009). Municipalities, generally responsible for management of waste in the cities, have the challenge to afford an efficient and effective system for the inhabitants. Nevertheless, there are problems beyond their abilities to cope with (Sujauddin et al., 2008) mostly because of the lack of financial resources, proper organization, complexity and system multi dimensionality (Burntley, 2007).

In recent years, a lot of research studies and papers have been done to specify useful and influential factors affecting waste management system in cities of developing countries. The elementary goals of solid waste management strategies are to address the aesthetic, land use, economic concerns, health and environmental aspects connected with the inappropriate disposal of waste (Henry et al., 2006; Nemerow, 2009;
Wilson, 2007). These issues are current and ongoing concerns for individuals, corporations, municipalities and nations throughout the world (Nemerow, 2009), as well as the universal community at large scale (Wilson, 2007). In developing countries, waste is generated by burgeoning towns is overwhelming domestic authorities and the central government in a similar way (Tacoli, 2012; Yousif and Scott, 2007).

Besides, restricted resources result in the aggravation and perpetuation of inequalities already is being experienced by most of the vulnerable population (Konteh, 2009; UNDP, 2010). There are some models and analyses like system analyses - engineering models, analysis platforms, and assessment tools which are mainly targeting firmly defined engineered systems - and have been applied to assist agencies which are active in SWM in developed countries since 1960s (Chang et al., 2011). In addition, these system models have been utilized both as monitoring and optimizing the current SWM systems and as a decision support device for planning processes. However, there are some system analysis devices which have been utilized in 
developing countries (e.g. see Charnpratheep and Garner, 1997; Chang et al., 1997; Chang and Wang, 1996), majorities of these models were developed in United States and Canada (Chang et al., 2011).

While approximately all system analyses haven been failed at obtaining a wide system perspective of SWM, there is a need for holistic and integrating methods which address the interconnection of environmental, economic, technical and socio-cultural scopes, and this need is especially potent in developing countries particularly in low income ones, the complication of the SWM systems are frequently higher for a number of reasons, and the SWM segment is principally preoccupied with collection-removal services (Wilson, 2007).

Cities have undergone a quick urbanization in last 50 years. However, the number dwellers is expected to double between 1987 till 2015. Besides, approximately 90 percent of this rise will occur in developing world, where rates of growth exceed 3 percent annually, three times more than developed countries (UN-HABITAT 2003).

Furthermore, Urbanization in the developing countries implicates the expansion of current slum zones and the emergence of new ones. In the 1990's, the urban population in low income countries expanded by one third. According to the report published by UNHABITAT in 2003, almost one billion people live in slums, or nearly one third of the world's city dwellers. If the current trends maintain, two billion people would be living in these areas by 2030 (UN-HABITAT 2003).

Future demand for waste collection is slum areas, therefore is presumably to put added strain on municipalities already unable to afford the service to their present habitants. Besides, increasing population levels intensifies the pressure on urban infrastructure in most of the cities already overburdened with the preparation of urban service. Also, many cities in developing countries lack the resources to get the need for services for instance water, solid waste management and sanitation.

Additionally, there are many cities in Africa and India which collect less than half of the waste that it is generated by their inhabitants. In a global scale, more than two third of human waste are dumping into the environment with little or no treatment, resulting in a degradation of urban environment in the form of water, land pollution and air which trigger risk to environment and human health (Suez Lyonnaise des Eaux 1998).

Besides, solid waste management in developing countries especially low income ones has received less attention from academics and politicians in comparison to other urban environmental challenges and problems like wastewater treatment and air pollution. Nonetheless, the inappropriate handling and disposal of solid waste builds severe problem such as; high morbidity and mortality rate in most of the cities.

Unfortunately, human activities create waste, and the manner these wastes are stored, handled, collected, transferred, transported and disposed of, absolutely pose serious risks to public health and environment. Where intensive human activities concentrate, such as in urban centers, the proper and secure solid waste management actions are of most importance to permit healthy living conditions for the inhabitants. This fact has been approved by the most of governments, however a lot of municipalities are struggling to afford the most elementary and basic services. Typically one to two thirds of solid waste produced is not collected (World Resources Institute, et al., 1996). As a consequence, the uncontrolled waste that is often mixed with animal and human excreta is dumped altogether in the avenues and in drains, hence contributing to flooding, breeding rodent vectors, insects and the spread of diseases (UNEP-IETC, 1996). Besides, most of the municipal solid waste in low income developing countries which is collected is dumped on land in an unmonitored and uncontrolled way.

Such insufficient waste disposal creates severe environmental problems which affect wellness of humans and animals and bring about serious economic and welfare losses. In addition, the environmental deterioration caused by insufficient disposal of waste can contaminate surface and ground water through seeping of the leachate, soil contamination through direct waste connection or leachate, air pollution by open burning of wastes, spreading of infectious diseases by various vectors like insects, birds and rodent, or uncontrolled release of methane gas by anaerobic decomposition of waste all over the cities. It is unfortunate that urban suffer mostly from the lifethreatening conditions deriving from the inappropriate SWM (Kungskulniti, 1990; Lohani, 1984). Besides, as municipalities tend to allot their restricted financial resources to the wealthier zones of higher tax yields where inhabitants with more political power reside.

Usually, rich inhabitants use up part of their revenue to avoid direct exposure to the environmental problems next to their backyard, and problems are shifted away from their neighborhoods to somewhere else. Therefore, although environmental problems at the neighborhood level may recede in higher income zones, citywide and local environmental deterioration, due to a deficient SWM, remains or increases.

\section{LITERATURE REVIEW}

Past studies identified the people or stakeholders or organizations which may have an interest in sufficient waste management. The stakeholders are local and national government (Shekdar, 2009); municipalities; city corporations; non-governmental organizations (NGO's); households (Sujauddin et al., 2008); private contractor; Ministries of Health; Environment, 
Economy and Finance (Geng et al., 2009) and recycling companies (Tai et al., 2011).

Some researchers have recognized factors affecting the elements of the waste management systems. According to Sujauddin et al. (2008) waste generation is affected by size of the family, the level of education and monthly revenue. Family attitudes pertained to separation of waste are influenced by the active investment and support of the real estate company, community residential committees' involvement for public participation, and fee for collection service according to volume or weight of waste (Zhuang et al., 2008; Scheinberg, 2011).

Besides, gender, peer influence, land size, being a member of environmental association and household location illustrate the waste utilization and separation behavior of the household (Ekere et al., 2009). It has been related that the practices like collection, transfer and transport are influenced by inappropriate bin collection system, poor road planning, lack of data and information regarding the schedule of collection, inadequate infrastructure, weak route and number of vehicles for waste collection (Hazra and Goel, 2009; Moghadam et al., 2009; Henry et al., 2006). Furthermore, organizing the unofficial segments and boosting micro-enterprises were said by Sharholy et al (2008) as an impressive methods of expanding affordable waste collection services.

Lack of knowledge and science of treatment systems by local and national authorities is brought asone factor influencing the waste treatment (Chung and Lo, 2008). Tadesse et al 2008, analyzed the factors which affect household waste disposal decision making. The outcomes demonstrated which supply of waste facilities substantially affects the choice of waste disposal. Insufficient supply of the containers and longer haul to these containers increase the contingency of waste dumping in an open areas and roadsides related to the usage of communal containers.

Besides, inadequate fiscal resources restricting the security and safe disposal of waste in well-equipped and engineered landfills and lack of regulation is mentioned by Pokhrel and Viraraghavan (2005). In relation to the cost of disposal Scheinberg (2011), analyzed the data from solid waste management in the world's cities (Scheinberg et al., 2010), notes that there are indexes which high rates of recovery are connected with tipping prices at the disposal site. High disposal costs has the influence of more recovery of waste produced, which goes to the value chains or beneficial reuse of waste.

According to Gonzalez-Torre and Adenso-Diaz (2005) factors like social influences, altruistic and regulatory are some of the proofs why certain communities improve potent recycling programs. Besides, the authors also illustrated that people who continuously go to the bins to dispose of general refuse are more likely to participate in recycling programs at home, and in many cases, number of the citizens who participate in separation and collection programs at home increase as the distance to the recycling dustbins decrease. Minghua et al. (2009) mentioned that in order to rise recycling rate, the local authorities and national government have to motivate markets for recycled materials and enhancing professionalism in recycling companies. Furthermore, other factors stated by other researchers are fiscal support for recycling projects and plans and infrastructures (Nissim et al., 2005). Management of waste is also influenced by the aspects or enabling factors which facilitate the function of the system which are legal, institutional, socio-cultural, technical and environmental.

Literature proposes that technical factors affecting the system are pertain to the lack of technical skills amongst personnel within municipalities and government authorities (Hazra and Goel, 2009), insufficient infrastructure, poor roads and out of date vehicles, inadequate technologies and reliable information and data respectively offers which the factors influencing the environmental aspects of solid waste management in developing countries are the lack of evaluation of actual impacts and as well as environmental control systems (Moghadam et al., 2009; Mrayyan and Hamdi, 2006; Matete and Trois 2008; Asase et al. 2009).

Ekere et al. (2009) suggested that the involvement of the population in active environmental organizations is essential to have better systems. Municipal authorities have been unsuccessful to manage solid waste because of fiscal factors. The massive expenses required to afford the services, the absence of financial support, restricted resources, the unwillingness of the users to pay for service and lack of appropriate use of economic instruments have prevented the delivery of appropriate waste management services (Sharholy et al., 2007; Sujauddin et al., 2008).

sharholy et al. (2008) represented that involvement of the private segment is a factor which could develop the efficiency of the system. It is usually regarded that waste management is the solitary task and liability of local authorities, and that the public is not assumed to participate (Vidanaarachchi et al., 2006). The operational efficiency of solid waste management rely on the active contribution of both the municipal agency and the citizens. Hence, socio-cultural aspects stated by some researchers include people participating in decision making, community awareness and societal apathy for participating in solutions (Sharholy et al., 2008; Moghadam et al., 2009).

Besides, management deficits are frequently considered in the municipalities. Some scholars which have investigated the institutional factors which influence the system have come to the conclusion which domestic waste management authorities have a lack of leadership and occupational knowledge. Furthermore, it is concluded that the data existing is so marginal from the public domain (Chung and Lo, 2008). The very limited data and information is not complete or is scattered around different agencies connected. Therefore, it is extremely tough to achieve a vision into the intricate problem of municipal solid waste management (Seng et al., 2010).

In addition, waste workers are connected to low social status (Vidanaarachchi et al., 2006) situation which gives as a consequence of low passion amongst the 
solid waste employees. Politicians give low preference to solid waste compared to other activities belong to municipalities (Moghadam et al., 2009) with the final result of limited trained and skillful personnel in municipalities (Sharholy et al., 2008). Affirmative factors stated that develop the system are support from municipal authorities and strategic plans for waste management which permits monitoring and valuation of the system annually (Zurbrügg et al., 2005; Asase et al., 2009). Scholars have recorded how an insufficient ligitimate framework contributes affirmatively to the improvement of the integrated waste management system while the lack of satisfactory policies and poor legislations are adverse to it.

A typical waste management system is shown in figure 1 in a low-income countries that can be depicted by the elements:

- Generation and storage of household waste

- Reuse and recycling on household level including composting

- Primary waste collection and transport to transfer station or community bin

- The transfer station or community bin management

- Secondary collection and transport to the waste disposal site

- Disposal of waste in landfills

Recovering and recycling generally occur in all elements of the systems and it is broadly practiced by unofficial segment called waste pickers or by the solid waste management staff for the added revenue. Beside, recovered and recycled commodities then enter a chain of dealers, or processing prior to be sold to manufacturing enterprises.

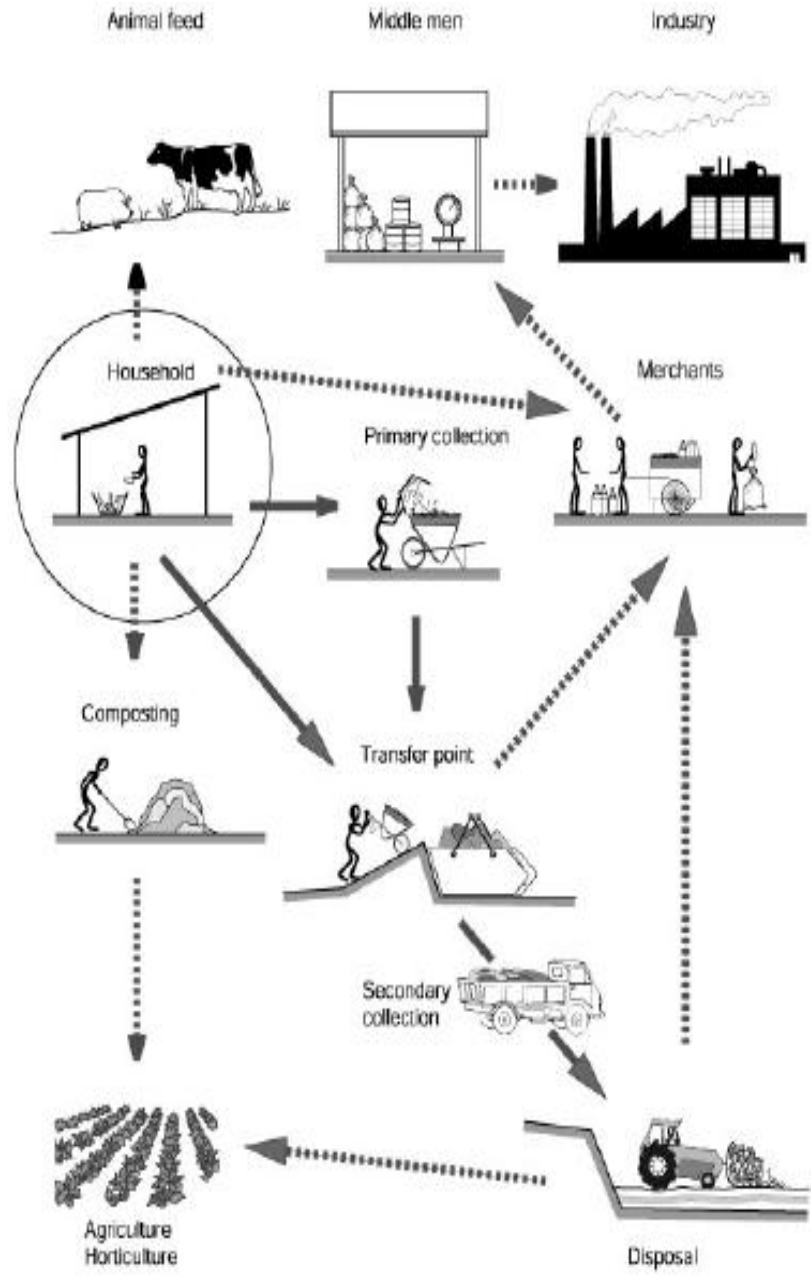

Figure 1: Typical elements of a solid waste management system in low- or middle-income countries (source: SANDEC/EAWAG)

\section{SOLID WASTE MANAGEMENT IN DEVELOPING COUNTRIES}

For a variety of reasons, poor waste management practices and its implications to public health remain acutely troublesome in many developing countries a century and a half after the European sanitary revolution, despite enhancing globalization (Konteh, 2009). In industrial countries, benefits of health from solid waste and sanitation systems are hugely taken for granted, and the concentration has switched from sanitation-related communicable disease to diseases of affluence such as cancer drug and alcohol abuse and cardiovascular disease and sustainability (Konteh, 2009; Langeweg et al., 2000; McGranahan, 2001).

Meanwhile, most of low income developing countries are presently influenced by the 'double burden' of the combined effects of the diseases of affluence and communicable disease (Boadi et al., 2005; Konteh, 2009). Wilson (2007, p. 204) demonstrates that "in some countries, simple survival is such a predominant concern, that waste management does not feature strongly on the list of public concerns". Furthermore, when SWM is on the public agendum in low income 
developing countries, it is driven by the same concerns same as industrialized countries, though it tends to be driven most potently by public health; the key preference is still getting the waste out from under backyard as it was for Europe and the United States till 1960s (Coffey and Coad, 2010; Memon, 2010; Rodic et al., 2010; Wilson, 2007).

Environmental protection is still relatively slight on the public and political schedule, although this is going to change (Wilson, 2007). Although the regulation and legislation is frequently in place requiring closure and phasing out of unregulated disposal, implementation tends to be poor (Wilson, 2007). The resources validity of waste is an essential motive in many low income developing countries nowadays; unofficial recycling affords a livelihood for the urban poor in many sections of the world (UN-HABITAT, 2010; Wilson, 2007). Besides, climate change is a significant motive worldwide - the clean improvement mechanism under the Kyoto protocol, in which improved countries can purchase 'carbon credits' from low income developing nations, can afford a vital source of revenue to motivate cities in developing countries to develop waste management systems (Wilson,2007).

Swift urbanization is occoring particularly in low income nations. Universally, in 1985, almost $41 \%$ of world population lived in urban zones, and by 2015 it is assumed to increase to $60 \%$ (Schertenleib, 1992). In addition, of this urban population $68 \%$ will be living in th towns of low income and lower middle income countries (figure 2).

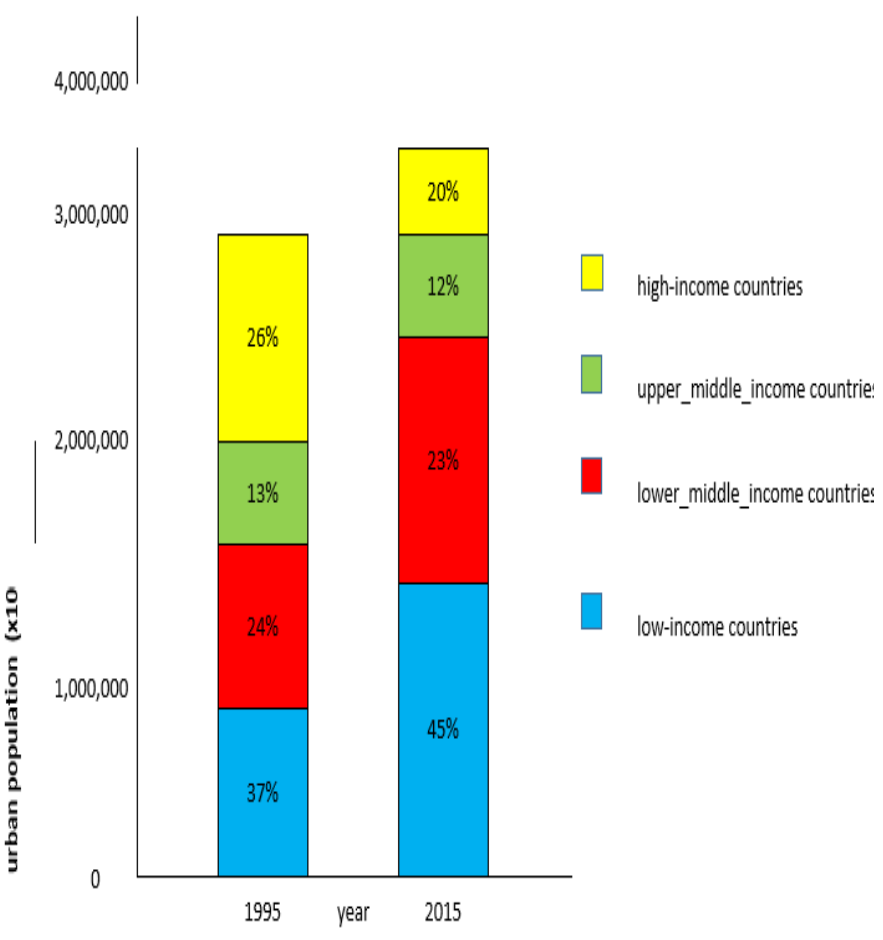

Figure 2: Global urban population categorized by of different economies (Schertenleib, 1992). Economies are divided according to 1996 GNP per capita: low income < 785 US\$; low middle income 786-3115 US\$; upper middle income
3116-9635 US\$, and high income > 9636

US\$ (http://www.worldbank.org/data/databytopic/class.htm)

There are many similarities which exist between the historical SWM improvement path of industrialized countries and the present path of developing countries. Beside, a lot of cities in lower income nations are experiencing same situations to those of the $19^{\text {th }}$ century in high income countries; "deteriorating sanitary conditions, unprecedented levels of morbidity and mortality and high levels of urbanization which influenced mainly the working class population" (Konteh, 2009, p. 70).

In point of fact, increasing urbanization and socioeconomic disparities, insufficient provision of sanitary and environmental facilities, social deprivation and inequalities pertain to current SWM systems, and high levels of morbidity and mortality connected to insufficient sanitation, waste disposal and water supply provision were joint particularly in poorer urban neighborhoods in lower income nations (Konteh, 2009).

In spite of the obvious parallels, the context in which developing countries are proper is absolutely different from the historical contexts of developed ones. Besides, quick urbanization, ascending inequality and the tension for growth in economy; varying economic, cultural, socio-economic, and political outlooks; governance, institutional, and liability issues; and international influences have created locally specific, technical and non-technical challenges of broad complication (see figure 3 ).

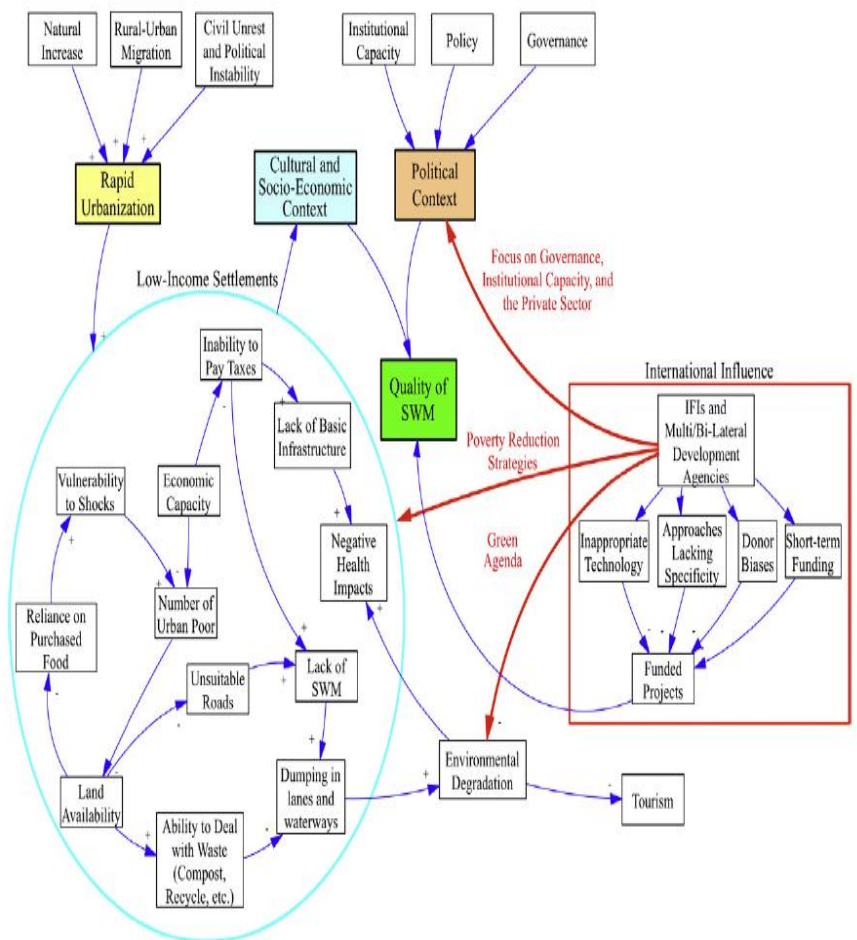

Fig. 3. Developing country SWM context. 


\section{DIFFERENCES BETWEEN DEVELOPED AND DEVELOPING COUNTRY CITIES THAT AFFECT MSWM}

There are a deep differences exist between developed and developing countries in terms of revenue, consumption patterns, institutional capacity, capital available for urban investment and standard of living. Conventional solution generally do not count these differences, resulting in less than optimized outcomes. Table 1 give an outline of the waste production per capita as well as total waste production in countries of different revenue levels. Inhabitants of low income nations are willing to produce less garbage than inhabitants in wealthier zones. For example, China with billion-plus population, increasing economy and developing standard of living exceled the US as the world's largest producer of solid waste in 2005. If the present trends remain, India will also produce more total waste than US in 2025 (Medina 2008a, b).

Table 1: Waste generation per capita and total waste generation

\begin{tabular}{|c|c|c|}
\hline \multicolumn{2}{|c|}{$\begin{array}{c}\text { Waste generation rate } \\
\text { (lbs/person/day) }\end{array}$} & $\begin{array}{c}\text { Total waste generation } \\
\text { (million tons/year) }\end{array}$ \\
\hline Low-income countries & 1.3 & 569 \\
\hline Middle-income countries & 1.8 & 986 \\
\hline High-income countries & 3.1 & 566 \\
\hline
\end{tabular}

The below illustrate the major differences between developing and developed countries that pertain to the layout of MSWM solutions:

- Developed nations benefit a relative affluence of capital and enjoy high labor prices, while developing ones have a relative rarity of capital and affluence of inexperienced and cheap labor. It makes sense for the former to improvise waste management systems centralized in capital and that save in the prices of labor, however, it continuously does not make sense for the latter to pursue the similar approach.

- The physical specifications of towns in developing and developed nations vary noticeably. Besides, towns in the developing ones have the wide areas with substandard conditions - slums with narrow, hilly, and unpaved avenues. Most of immigrants cannot afford to buy land on which to construct their houses. As a consequence, some of them occupy empty land and become squatters. Most of the zones which lack refuse collection services are slum and squatter settlements. Besides, some domestic authorities reject to provide refuse collection to squatters due to not paying taxes. This refusal to afford waste collection has a detrimental influence on the urban milieu.

- An essential difference between developing and developed nations refers to the heterologous amount and specifications of waste produced. The waste produced tends to rise as revenue growths. Further, in addition to low-income societies generating less refuse, the combination of the waste also tends to be different. Waste produced in developing nations involves a huge percentage of organic substances, generally three times more than that of developed ones. Besides, the waste is also more intense and wet, because of the common consumption of fresh fruits and vegetables, as well as unpacked food. In developed nations residents consume more processed food and food packed in cans, bottle, plastics and jars containers than in developing counterparts. As a consequence, waste produced in the former contains high percentage of packaging materials than in that of latter.

- Multitude cities in the developing nations tolerate a dynamic unofficial segment which has evolved around waste, that provides revenue chances for recent migrants, unemployed, children, women, old people, and handicapped peoples. The most joint jobs are informal refuse collection and scavenging because of their significance.

\section{CURRENT CHALLENGES}

Collection, transportation, and disposal of MSW demonstrates a huge expense for developing nation cities: management of waste generally accounts 30 to 50 percent of municipal operational budgets. Despite these high expenditures, cities collect just 50 to 80 percent of the refuse produced. For instance, in India as a developing countries about 50 percent of refuse produced is collected. Disposal receives less attention: as much as 90 percent of the MSW collected in developing cities ends up in an open dumps (Cointreau 2008; Medina 1997a).

Besides, in areas which lack refuse collection generally low-income communities inhabitants tend either to dump their rubbish at the closest empty lots, public space, creek, or river, or simply burn it in their backyards. Uncollected waste can stack on the avenues and block drains when it rains, which might lead to flooding. Furthermore, waste can also be carried away by run-off water to lakes, seas and rivers, influencing those ecosystems. Another option is to end up waste in an open dumps, whether legal or illegal: the most popular disposal technique in the developing nation. Open dumping of solid waste produces different environmental and health hazards. The decommission of organic substances generates methane gas which can bring about fire and explosions, and contributes to global warming and climate change.

The biological and chemical processes which take place in an open dumps generate potent leachates, which contaminate surface and groundwater. Furthermore, fires periodically break out in open dumps, producing smoke and contributing to air pollution. For instance, in 
the Mexican city of Tampico, on the Gulf of Mexico coast, a fire burned for over six months at the local open dump. Fires at open dumps frequently begin spontaneously, leaded to the methane and heat produced by biological decomposition. Besides, dump managers in some cities intentionally periodically set fire at the dumps in order to decrease the tonnage of the waste, which permits higher waste to be disposed there and hence expands the life of the dumps.

In addition, human scavengers might also lead deliberate fires, since metals are easier to spot and recover amongst the ashes after the fire than amongst piles of mixed wastes. Food dregs and kitchen waste attract rats, flies, birds and other kinds of animals to the dumping sites. Animal feeding at the dump sites can transmit diseases to humans living in the adjacency. Biodegradation of organic substances could last decades, which might restrict the future usage of the land on which open dump sites are located.

\section{CURRENT PERSPECTIVES: 'EMERGING' AND DEVELOPING NATIONS}

\subsection{Public health}

There are possible hazards to environment and health from inappropriate handling of solid wastes. The direct health hazards concern majorly the workers in the field, who require to be protected, as far as possible, from contact with waste. Besides, there are also particular hazards in handling wastes from hospitals and health centers. For the general public, the major hazards to health are indirect and come from the breeding of disease vectors, elementary flies and rats.

Uncontrolled hazardous waste from industries with the mixture of municipal wastes produce possible hazards to human health. Traffic accidents can cause toxic spilled wastes. There is particular peril of concentration of heavy metals in the food supply and chain, a difficulty which demonstrates the relationship between liquid industrial effluents involving heavy metals and municipal solid wastes which are discharged to a drainage/sewerage system and or open dumping sites of municipal solid wastes and the wastes discharged thereby keeps a bad cycle containing there some other types of difficulties which are chemical poisoning through chemical inhalation. Besides, uncontrolled waste can obstruct the runoff from storm water resulting flooding. Low birth weight, cancer, congenital malformations, neurological disease, nausea and vomiting, mercury toxicity from eating fish with levels of mercury in the river, plastic found in shores ingested by birds, resulted in high algal population in lakes and rivers and seas, deteriorates water and soil quality.

\subsection{Environment}

The disintegration of waste into constituent chemical materials is a usual source of domestic environmental pollution. This problem is particularly severe in developing countries. There are very few landfills in those poor countries which meet environmental standards which is approved in developed countries requirements, and with finite budgets there are presumably to be few sites strictly evaluated prior to use in near future.

The problem and obstacle is compounded by the issues connected with quick urbanization. Besides, a main environmental concern is release of gas by decomposing garbage. Methane is a by-product of the anaerobic respiration of bacteria, and these bacteria prosper in landfills with huge amounts of moist. In addition, methane concentrations can reach up to 50 percent of the composition of landfill gas at the maximum anaerobic decomposition.

Furthermore, a secondary problem with these gases is their participation to the enhanced greenhouse gas effect, global warming and climate change. The leachate management differs all over the landfills of the developing nations. Leachate demonstrates a menace to domestic surface and ground water systems. The usage of compact clay deposits at the bottom of the waste pits, coupled with plastic sheeting-type liners to avoid infiltration into the surrounding soil, is usually regarded as the optimized strategy to involve excess liquid. In this way, waste is motivated to be evaporated rather than infiltrate.

\section{CONCLUSION}

All in all, waste management in the developing countries is unfavorable, unsatisfactory and unaccepted. The inappropriate management of solid waste illustrates a source of air, land, and water contamination, and demonstrates hazards to human health and the environment. Besides, despites remarkable expenditure, the situation will tend to degrade further because of the quick increase of cities which is presumably to take place over the next few decades. Globalization could rise the amount of waste which requires to be collected, transported, and disposed of, further straining cities in developing countries in Africa, Asia, and Latin America. Conventional solutions to waste management in the developing countries frequently depend on high technology, high cost, bureaucratic, and intensive alternatives. In addition, conventional solutions generally do not view the deep differences between rich and low-income and middle-income nations, resulting in less than optimized consequences. Furthermore, conventional solutions continuously contain the transfer of waste management technique from developing to developed nations. International improvement banks and mutual development agencies tend to favor this transfer technology. The experience on the usage of progressive technique in developing nations. However, has been hugely negative. Conventional waste management solutions generally neglect the possible contribution of the unofficial segment. Scavengers and informal reuse collectors give obvious economic and environmental profits to the community, and their activities should be developed and supported. Besides, a decentralized system would be more proper to the prevalent conditions in the developing countries. Successful usage of the low technology approaches, and the incorporation of unofficial refuse collectors and scavengers exist in different developing countries in Africa, Asia and Latin America. A decentralized system could assist to solve the apparently intractable problems 
and obstacles of the waste management in developing country cities in an socially favorable, economically reliable and environmentally sound manner.

\section{REFERENCES}

Minghua, Z., Xiumin, F., Rovetta, A., Qichang, H., Vicentini, F., Bingkai, L., Giusti, A., Yi, L., 2009. Municipal solid waste management in Pudong New Area, China. Journal of Waste Management 29, 12271233.

Sujauddin, M., Huda, M.S., Rafiqul Hoque, A.T.M., 2008. Household solid waste characteristics and management in Chittagong, Bangladesh. Journal of Waste Management 28, 1688-1695.

Burntley, S.J., 2007. A review of municipal solid waste composition in the United Kingdom. Journal of Waste Management 27 (10), 1274-1285.

Henry, R.K., Yongsheng, Z., Jun, D., 2006. Municipal solid waste management challenges in developing countries - Kenyan case study. Journal of Waste Management 26, 92-100.

Nemerow, N.L., 2009. Environmental Engineering: Environmental Health and Safety for Municipal Infrastructure, Land Use and Planning, and Industry, sixth ed. Wiley, Hoboken, N.J..

Wilson, D.C., 2007. Development drivers for waste management. Waste Management \& Research 25 (3), 198-207.

Tacoli, C., 2012. Urbanization, Gender and Urban Poverty: Paid Work and Unpaid Carework in the City. International Institute for Environment and Development: United Nations Population Fund, London, UK.

Yousif, D.F., Scott, S., 2007. Governing solid waste management in Mazaten Konteh, F.H., 2009. Urban sanitation and health in the developing world: reminiscing the nineteenth century industrial nations. Health \& Place 15 (1), 69-78.

UNDP, 2010. Regional Human Development Report for Latin America and the Caribbean 2010. United Nations Development Programme, Costa Rica.

Charnpratheep, K.S., Garner, B., 1997. Preliminary landfill site screening using fuzzy geographical information systems. Waste Management and Research 15 (2), 197-215.

Chang, N.B., Chen, Y., Wang, S., 1997. A fuzzy interval multiobjective mixed integer programming approach for the optimal planning of solid waste management systems. Fuzzy Sets and Systems 89 (1), $35-60$.

Chang, N.B., Wang, S., 1996. Managerial fuzzy optimal planning for solid waste management systems. Journal of Environmental Engineering 122 (7), 649-658.
Chang, N.B., Pires, A., Martinho, G., 2011. Empowering systems analysis for solid waste management: challenges, trends and perspectives. Critical Reviews in Environmental Science and Technology 41 (16), 1449-1530.

Morrissey, A.J., Browne, J., 2004. Waste management models and their application to sustainable waste management. Waste Management 24 (3), 297-308.

Shmelev, S., Powell, J., 2006. Ecological-economic modelling for strategic regional waste. Ecological Economics 59 (1), 115-130.

UN-HABITAT (2003). The Challenge of Slums: Global Report on Human Settlements 2003. London: Earthscan.

Suez Lyonnaise des Eaux (1998). 'Alternative Solutions for Water Supply and Sanitation in Areas with Limited Financial Resources'. Nanterre: Suez Lyonnaise des Eaux.

World Resources Institute, United Nations Environment Programme, United Nations Development Programme, The World Bank, 1996. World Resources 1996-97 The Urban Environment, Oxford University Press, Oxford.

UNEP-IETC, HIID, 1996. International Source Book on Environmentally Sound Technologies for Municipal Solid Waste Management, United Nations Environment Programme (UNEP), International Environmental Technology Centre (IETC).

Kungskulniti, N., 1990. Public Health Aspects of a Solid Waste Scavenger Community in Thailand, Waste Management \& Research 8(2), 167-170.

Lohani, B. N., 1984. Recycling Potentials of Solid Waste in Asia through Organised Scavenging, Conservation \& Recycling 7(2-4), 181-190.

Shekdar, A., 2009. Sustainable solid waste management: an integrate

Sujauddin, M., Huda, M.S., Rafiqul Hoque, A.T.M. 2008. Household solid waste characteristics and management in Chittagong, Bangladesh. Journal of Waste Management 28, 1688-1695.

Geng, Y., Zhu, Q., Doberstein, B., Fujita, T., 2009. Implementing China's circular economy concept at the regional level: a review of progress in Dalian, China. Journal of Waste Management 29, 996-1002.

Tai, J., Zhang, W., Che, Y., Feng, D., 2011. Municipal solid waste source-separated collection in China: a comparative analysis. Journal of Waste Management $31,1673-1682$.

Zhuang, Y., Wu, S.W., Wang, Y.L., Wu, W.Z., Chen, Y.X., 2008. Source separation of household waste: a 
case study in China. Journal of Waste Management 28, 2022-2030.

Scheinberg, A., 2011. Value added: modes of sustainable recycling in the modernisation of waste management systems. Ph.D. Wageningen University, Netherlands.

Ekere, W., Mugisha, J., Drake, L., 2009. Factors influencing waste separation and utilization among households in the Lake Victoria crescent, Uganda. Journal of Waste Management 29, 3047-3051.

Hazra, T., Goel, S., 2009. Solid waste management in Kolkata, India: practices and challenges. Journal of Waste Management 29, 470-478.

Moghadam, M.R.A., Mokhtarani, N., Mokhtarani, B., 2009. Municipal solid waste management in Rasht City. Iran Journal of Waste Management 29, 485-489.

Sharholy, M., Ahmad, K., Mahmood, G., Trivedi, R.C., 2008. Municipal solid waste management in Indian cities.A review. Journal ofWasteManagement 28, 459467.

Tadesse, T., Ruijs, A., Hagos, F., 2008. Household waste disposal in Mekelle city. Northern Ethiopia Journal of Waste Management 28, 2003-2012.

Chung, S., Lo, C., 2008. Local waste management constraints and waste administrators in China. Journal of Waste Management 28, 272-281.

Pokhrel, D., Viraraghavan, T., 2005. Municipal solid waste management in Nepal: practices and challenges. Journal of Waste Management 25, 555-562.

Scheinberg, A., 2011. Value added: modes of sustainable recycling in the modernisation of waste management systems. Ph.D. Wageningen University, Netherlands.

Scheinberg, A., Wilson, D.C., Rodic, L., 2010. Solid waste management in the World's Cities. UN-Habitat's Third Global Report on the State of Water and Sanitation in the World's Cities. EarthScan, Newcastleupon-Tyne, UK.

Gonzalez-Torre, P.L., Adenso-Diaz, B., 2005. Influence of distance on the motivation and frequency of household recycling. Journal of Waste Management 25, $15-23$.

Minghua, Z., Xiumin, F., Rovetta, A., Qichang, H., Vicentini, F., Bingkai, L., Giusti, A., Yi, L., 2009. Municipal solid waste management in Pudong New Area, China. Journal of Waste Management 29, 12271233.

Nissim, I., Shohat, T., Inbar, Y., 2005. From dumping to sanitary landfills - Solid waste management in Israel. Journal of Waste Management 25, 323-327.
Matete, N., Trois, C., 2008. Towards zero waste in emerging countries - A South African experience. Journal of Waste Management 28, 1480-1492.

Henry, R.K., Yongsheng, Z., Jun, D., 2006. Municipal solid waste management challenges in developing countries - Kenyan case study. Journal of Waste Management 26, 92-100.

Mrayyan, B., Hamdi, M.R., 2006. Management approaches to integrated solid waste in industrialized zones in Jordan: a case of Zarqa City. Journal of Waste Management 26, 195-205.

Asase, M., Yanful, E.K., Mensah, M., Stanford, J., Amponsah, S., 2009. Comparison of municipal solid waste management systems in Canada and Ghana: a case study of the cities of London, Ontario, and Kumasi, Ghana. Journal of Waste Management 29, 2779-2786.

Ekere, W., Mugisha, J., Drake, L., 2009. Factors influencing waste separation and utilization among households in the Lake Victoria crescent, Uganda. Journal of Waste Management 29, 3047-3051.

Sharholy, M., Ahmad, K., Vaishya, R.C., Gupta, R.D., 2007. Municipal solid waste characteristics and management in Allahabad, India. Journal of Waste Management 27, 490-496.

Sujauddin, M., Huda, M.S., Rafiqul Hoque, A.T.M., 2008. Household solid waste characteristics and management in Chittagong, Bangladesh. Journal of Waste Management 28, 1688-1695.

Vidanaarachchi, C.K., Yuen, S.T.S., Pilapitiya, S., 2006. Municipal solid waste management in the Southern Province of Sri Lanka: problems, issues and challenges. Journal of Waste Management 26, 920-930.

Seng, B., Kaneko, H., Hirayama, K., KatayamaHirayama, K., 2010. Municipal solid waste management in Phnom Penh, capital city of Cambodia. Waste Management \& Research 29, 491-500.

Zurbrügg, C., Drescher, S., Rytz, I., Sinha, M., Enayetullah, I., 2005. Decentralised composting in Bangladesh, a win-win situation for all stakeholders. Resources, Conservation and Recycling 43, 281-292.

Mrayyan, B., Hamdi, M.R., 2006. Management approaches to integrated solid waste in industrialized zones in Jordan: a case of Zarqa City. Journal of Waste Management 26, 195-205.

C. Zurbrugg, February 2003, USWM-Asia

Konteh, F.H., 2009. Urban sanitation and health in the developing world: reminiscing the nineteenth century industrial nations. Health \& Place 15 (1), 69-78.

Langeweg, F., Hilderink, H., Maas, R., 2000. Urbanisation, Industrialisation and Sustainable Development Globo Report Series No. 27: RIVM. 
McGranahan, G., 2001. The Citizens at Risk: From Urban Sanitation to Sustainable Cities. Earthscan: Stockholm Environment Institute, London, Sterling, VA.

Boadi, K., Kuitunen, M., Raheem, K., Hanninen, K., 2005. Urbanisation without development: environmental and health implications in African cities. Environment, Development and Sustainability 7 (4), $465-500$.

Coffey, M., Coad, A., 2010. Collection of Municipal Solid Waste in Developing Countries. UN-HABITAT, Malta.

Memon, M.A., 2010. Integrated solid waste management based on the $3 \mathrm{R}$ approach. Journal of Material Cycles and Waste Management 12 (1), 30-40.

Rodic, L., Scheinberg, A., Wilson, D.C., 2010. Comparing Solid Waste Management in the World's Cities. Paper Presented at the ISWA World Congress 2010, Urban Development and Sustainability - A Major Challenge for Waste Management in the 21st Century, Hamburg, Germany.

Schertenleib, R., Meyer, W., 1992. Municipal Solid Waste Management in DC's: Problems and Issues; Need for Future Research, IRCWD News (No. 26), Duebendorf, Switzerland.

Medina, M. (2008a). 'The Informal Recycling Sector in Developing Countries: Asset or Liability?' GRIDLINES. Washington, DC: World Bank.

Medina, Martin (2010): Solid wastes, poverty and the environment in developing country cities: Challenges and opportunities, Working paper // World Institute for Development Economics Research, No. 2010, 23, ISBN 978-92-9230-258-0 